\title{
NEW BUTTERFLY RECORDS FOR SASKATCHEWAN AND ALBERTA
}

\author{
by Ronald R. Hooper, Fort Qu'Appelle
}

I recently received a shipment of butterflies back from Mr. C. F. Dos Passos of Mendham, New Jersey, confirming six new species records for Saskatchewan and one for Alberta. The Saskatchewan specimens were all collected in the Tantallon area, in July, 1966, while I was collecting insects for the Saskatchewan Museum f Natural History. This area is one of the few places in Saskatchewan where the scrub oak (Quercus macrocarpa) grows in abundance. It is also an important area in that some eastern species of wildlife seem to extend their range westward from Manitoba along the $\mathrm{Qu}$ 'Appelle Valley here.

LEA S T SKIP P E R (Ancyloxipha numitor Fabricius). Five specimens were collected on July 8, 1966 east of Tantallon along a spring-fed stream on the north slope of the valley. These tiny butterflies were found darting among the sedges where the water was ankle-deep, thus making it somewhat difficult for the collector. I have taken this species before at Oak Lake, Manitoba, on June 30,1962 , on the blossom of an arrowhead (Sagittaria cuneata). The species has been taken at several other places in southern Manitoba. There is one specimen from Lethbridge, Alberta, in the Saskatchewan Museum of Natural History in Regina, that was collected by J. B. Wallis. This would indicate that the Least Skipper should be watched for throughout southern Saskatchewan. According to Dos Passos, these specimens could confirm the existence of what has been a questionable subspecies (A.n. longleyi French).

REAKIRT'S BLUE (Hemiargus isola isola Reakirt). One faded specimen was collected on yellow clover (Melilotus officinalis) along a roadside east of Tantallon on July 6, 1966. This appears to be the first record for the prairie provinces. The closest other records are from central Minnesota, from whence it may be a wind-blown sitray.

COLORADO BLUE (Philotes battoides centralis Barnes and McDunnough). One specimen was collected at Elkwater in the Cypress Hills of Alberta, June 18, 1963. This specimen had been left papered in my collection until last fall. I had thought it an Acmon Blue (Plebejus acmon), and therefore nothing new for Alberta, so I had not mounted it. This is the only specimen that I know of that has been collected in the prairie provinces. The closest records of Colorado Blue are from Missoula, Montana, and Kootenay, B.C. I know of no other records east of the Great Divide. I collected the specimen among scattered clumps of short grass on a dry, gravelly hill-top. It is in good condition. This species should now be watched for in the Cypress Hills of Saskatchewan.

BANDED HAIRSTREAK (Strymon falacer godarti Field). Three specimens were collected on July 8, 1966, east of Tantallon. These, and several other butterflies of this species that were seen, were among scrub oak which is probably the food plant in our area for this species. I captured the first specimen on the blossoms of meadowsweet (Spiraea alba). The other specimens were landed on low oak leaves. This is an eastern species of butterfly that has previously been taken as far west in Canada as Aweme and Cartwright in Manitoba. HARRIS' CHECKERSPOT (Melitaea harrisii hanhami Fletcher). Many specimens were collected in the tall, coarse grass of a wet meadow in the Qu'Appelle Valley east of Tantallon on July 7-9, 1966. Some specimens were also taken on alfalfa blossoms in a nearby field. This is an eastern species that has been taken previously as far west as Beulah and Birtle, Manitoba.

EYED BROW N (Lethe eurydice 
transmontana Gosse). One colony was discovered and several specimens collected in the marsh next to the wet meadow where the Harris' Checkerspot was found, the Eyed Brown seeming to prefer a wetter habitat. I took these specimens as I flushed them from the thick grassy cover of the marsh, July 7-9, 1966. This eastern species has also been taken previously as far west as Beulah and Birtle, Manitoba.

LITTLE WOOD SATYR (Euptychia cymela cymela Cramer). Many speci- mens were collected east of Tantallon, July 6-9, 1966. All specimens looked as if they had been on the wing for some time. They were hard to capture as they dodged through the thick hazel-nut bushes that grow around the oak trees. This eastern species has been taken before as far west as Beulah, Manitoba. I have an unauthenticated report of a specimen being taken by a Mr. Shaw in the Weyburn area. This specimen is somewhere in an American collection, and I have not been able to confirm its identity.

\section{HISTORY OF THE COUGAR IN SASKATCHEWAN}

\section{by Thomas White, $1-2105$ Cornwall St., Regina}

This article records stories I have collected over the last six years. Only two reports could be verified by hides obtained from the animals, but all were given in good faith by persons who remember the experience as exceptional. The wide distribution and the dates of the reports are interesting. Both the South and North Saskatchewan River valleys are ideal cougar habitat and it is questionable if the cougars that occupied it were wanderers. The cougars of the Pasquia Hills are far from the known cougar range, and it is likely that they have always been native to this area. Other reports may indicate that historically the cougar occurred elsewhere and it has always been an extremely rare native of Saskatchewan.

Historical reports of the cougar in Saskatchewan are of interest because cougars were previously considered to exist in Canada only in the mountains of British Columbia and Alberta, with an occasional wanderer roaming into the Cypress Hills in the southwestern part of Saskatchewan.

The writings of Ernest Thompson Seton (1929) contain no reference to cougars in Saskatchewan though he mentions almost every other province and state in North America. Young and Goldman (1946), whose book on the cougar is the most comprehensive so far published, give one record south of Kindersley and say that reports are extremely rare. The standard works on mammals either exclude the province entirely or put the extreme outer edge of the range in the Cypress Hills, although one has a question mark in the Pasquia Hills. Dewey Soper (1961a) states that there are unconfirmed reports of cougars being killed in the southern part of the province, mainly in the early part of the century when occurrences were rare and becoming rarer, and gives two probable records: in 1912 near old Fort Walsh, Cypress Hills, and in 1939 south of Kindersley as reported by Young and Goldman. Beck (1958) reports a 1948 record for Connell Creek, but states that cougars are occasional stragglers. A recent pamphlet by Victor Cahalane (1964) excludes most of the province, but shows an area in the west of the province above Lloydminster and Battleford where they are described as rare wanderers and probably not residen's, and a question mark in Manitoba west of Lake Winnipeg. Anderson (1946) writes that cougars ranged "east formerly to western Saskatchewan and northwestern North Dakota."

There are records of cougars in all the areas adjacent to Saskatchewan 